\title{
THE USE OF BRITISH BROADCASTING CORPORATION (BBC) PODCAST IN EFL STUDENTS' LISTENING SKILL IN IAIN PALANGKA RAYA
}

\author{
Desy Rachmiati' ${ }^{1}$ Imam Qalyubi ${ }^{2}$, Zaitun Qamariah ${ }^{3}$ \\ 1,2,3 State Islamic Institute of Palangka Raya \\ ${ }^{1}$ desyrachmiati@gmail.com, ${ }^{2}$ imamqalyubi@yahoo.com, ${ }^{3}$ zaitun.qamariah@iain-palangkaraya.ac.id
}

\begin{abstract}
A podcast is a digital multimedia file that can be downloaded to a portable media player, phone, or other device via the internet. There are many audio podcast that can be used in learning listening, one of them is British Broadcasting Corporation (BBC) podcast. This research aimed to describe how the contribution and the problems in using British Broadcasting Corporation (BBC) podcast in EFL students' listening skill. This research was conducted at IAIN Palangka Raya. The type of this study was a qualitative approach. The data was taken from interview and documentation. Eight EFL students and two lecturers in IAIN Palangka Raya were the subjects of this research. They were determined by purposive sampling technique. The findings reveal that the use of British Broadcasting Corporation (BBC) podcast give positive contribution to students' listening skill. Based on the result of the research using British Broadcasting Corporation (BBC) podcast can develop students' listening skill, vocabularies and they will be familiar with British accent. The problems in using the BBC podcast faced by the students were unfamiliar pronunciation, lack of vocabularies, and the speaker who spoke fast.
\end{abstract}

Keywords: Podcast, British Broadcasting Corporation (BBC) podcast, EFL students, listening skill

\section{INTRODUCTION}

Listening is a communicative activity in which listeners attempt to construct a reasonable interpretation of a text for some purpose (Nor, 2015). Listening is one of the essential skills. Yusnida et al. (2017) has stated that the skill of listening is a necessary part of communication and a basis for second language learning. Listening plays a vital role in communication, and to avoid misunderstanding during communication, listeners should have the ability to answer speakers' questions. In this case, doing classroom listening is slightly different from doing reallife listening. However, listening to classroom activities aims to accommodate real-life listening outside the classroom (Gestanti, 2017). Nevertheless, listeners and instructors of English as a foreign language (EFL) face a significant challenge in listening comprehension, which can lead to irritation, poor listener performance, or insufficient classroom attention (Maftoon \& Fakhri Alamdari, 2020).

Learning and teaching listening used to be characterized by the use of professionally generated newscasts, radio, and/or television programs. English language learners can now learn a variety of English language skill, thanks to new computer technology and internet tools such as podcasts. Podcasting, a key Web 2.0 technology, is a method of publishing audio or audio/video files to the Internet that enables users to subscribe to new files through an RSS feed and receive them automatically (Wei \& Ram, 2016). With some new ideas, podcasts will provide fresh ideas and inspiration. It covers a wide range of topics and offers a variety of recorded voice speeds (Lio \& Marafat, 2019). 


\section{Podcast as Media in Learning Listening}

According to Sulastri (2011) media is everything that is used to transfer the message from the senders to the receivers to stimulate the student's thought, feeling, attention, and interest so that the process of learning happens. In the teaching-learning process, media can serve as a facilitator. It has a lot of potential as a teaching tool (Bolla, 2014). Podcast is a media that can use in learning listening. Palenque (2016) clearly point out that using podcasts in the classroom helps teachers to vary their teaching methods while also allowing students to feel involved and a part of the learning environment.

Using authentic native speakers' tools, such as podcasts, is not a pedagogical technique, but it does include an authentic language background for native speakers who are fluent in their spoken language (Indahsari, 2020). Furthermore, podcasting is said to be an elective tool for exploring that can develop understudies' listening skills (NamazianDost et al., 2017). Teaching media helps the teacher in conducting teaching and learning activities in the class. It makes the teacher easier to deliver knowledge during the teaching process (Silmi, 2018). Therefore, using media in teaching, such as podcast is necessary, especially in teaching listening.

\section{The Use of Podcast in EFL Students}

According to Si (2019) English as a Foreign Language (EFL) is a term used to describe English as a second language. EFL stands for English as a Foreign Language, and it refers to people who study English in countries where English is not spoken. (for example, EFL learners are Indonesians who learn English in their own country). Furthermore, based on Prayatni (2019) when EFL students study English as a Foreign Language, English is not the primary language they master. Learning a foreign language is beneficial for a variety of reasons, including travel, communication with native speakers, and reading foreign articles. In teaching English skills in Indonesia, listening is one of the skills that are considered difficult but neglected (Agustiana, 2019). Since listening skills are one of the basic language skills, they should be taught with the same emphasis as the other basic language skills, such as reading, speaking, and writing.

Al Qasim \& Al Fadda (2013) In Saudi Arabia, they conducted a quantitative study with 46 female EFL students in higher education. The findings of this study revealed that using podcasts can improve EFL higher education students' listening comprehension in a positive and important way. This statement is in line with Widodo \& Gunawan (2019) who conducted quasiexperimental method. It was found that in EFL teaching and learning, a positive result was discovered regarding the impact of podcasts on students' listening comprehension.

\section{METHOD}

In this study the writer used interview and documentation. According to L. Cohen (2005) an interview is a dialogue between two people that is intended to collect research data in order to achieve research goals such as systematic definition, prediction, or interpretation. Interview were conducted to obtain information from the informant, it was eight EFL students and two lecturers of IAIN Palangka Raya. Meanwhile, in this study the researcher used a semi-structured interview. The topics and questions are given in a semi-structured interview, but the questions are open-ended, and the wording and order can be personalized to each interviewee, and the answers are given with prompts and probes. According to Arikunto (2010), documentation is written objects such as books, magazines, documents, regulations, notes, diaries, etc. By using documentation in this research, it supposed the data that would be found in this field. The 
researcher collected the scoring of listening from the eight students and the syllabus from the lecturers.

\section{RESULTS AND DISCUSSION}

\section{Results}

From the interview results, the interviewees said that using the BBC podcast in listening skills can give positive contribution to their listening skills, especially in the British accent. They also argued that the BBC podcast is a good podcast for learning listening skills. Moreover, using British Broadcasting Corporation (BBC) podcast in listening skill is necessary. When using British Broadcasting Corporation (BBC) podcast the students can develop their listening skill, vocabularies and they will be familiar in listening to British accent.

Many of students said that the problems when they listen to BBC podcast are the accent of British and vocabularies. The unfamiliar pronunciation in British accent is quite hard for them, also the lack of vocabularies adds more difficulties in listening to British Broadcasting Corporation $(\mathrm{BBC})$ podcast. Some of them also said that the problem that they got in listening to BBC podcast is the speakers that speak fast. So, that makes they cannot catch what the speakers say and hard to understand what the speakers talk about.

Furthermore, to solve the problems the students listen to the podcast more than once or repeat the British Broadcasting Corporation (BBC) podcast and listen the podcast in out of the classroom for their exercise.

According to the result of lecturers' interview, the problems that they got when using British Broadcasting Corporation (BBC) podcast are their students always said about their difficulties in listening what the speaker says, the podcast consumes a lot of time especially if the file is larger, uneasy to search appropriate podcast according to the syllabus, sometimes the information provided by podcasters is typically incomplete, and when the tools don't work properly.

\section{Discussion}

Based on the result of interview the students and lecturers, the researcher found that most of the students said that the use of British Broadcasting Corporation (BBC) podcast can give positive contribution to their listening skill. It is line with the research finding found by other researchers, utilizing podcast at teaching listening improved listening comprehension of Informatics Management at AMIK Mitra Gama (Melati et al., 2020).

Some of them also said when they listening to British Broadcasting Corporation (BBC) podcast make them know more about British accent, because BBC podcast is an authentic podcast that was made by British people and the speakers speak in British accent so it make the students can get more knowledge about British accent.

Furthermore, the use of British Broadcasting Corporation (BBC) podcast give a positive impact on students' vocabularies, learning motivation to listen the podcast, and they will be familiar in listening to native speaker conversation. The lecturers stated that the British Broadcasting Corporation (BBC) podcast is very useful and a good way to develop their students' listening skills. BBC podcast can help their students to learn more about pronunciation, especially the British accent. 
Then, when listening to BBC podcast the students become active listeners and listen on their own. It is in line with the statement that using podcasting in the classroom encourages students to use a variety of techniques to comprehend authentic topics at their own speed and in an anxiety-free setting (Ting, 2014).

According to the interview result with the students, the problems they got when listening to British Broadcasting Corporation (BBC) podcast were unfamiliar pronunciation, lack of vocabularies, and the speakers that speak fast. Because the BBC podcast using British accent in the content, that makes it more difficult for the students to understand what does mean by the speakers. As we know that British accent is one of the difficult accent in English.

Learners can listen to true and genuine materials on podcasts created by native English speakers (Hasan \& Hoon, 2013). Besides that, the British accent in the British Broadcasting Corporation (BBC) podcast also one of the advantages of this podcast. Although, listen to British Broadcasting Corporation (BBC) podcast is not easy, but if the students can understand and learn a listening skill from this podcast, it will give the students more knowledge, and of course, they can learn British accent from this podcast.

Furthermore, the lecturers give the statement that the problems they got in using British Broadcasting Corporation (BBC) podcast, as follows: (1) the students difficulties in listening what the speaker says (2) the students' limited vocabulary (2) consume a lot of time (3) it is not easy to search appropriate podcast according to the syllabus (4) sometimes the information is incomplete (5) and sometimes the tool doesn't work properly.

Based on the interview with the lecturers, they can overcome those problems by doing some actions, such as: (1) ask the students to listen to the podcast many times (2) manage time and frequency of using podcast (3) pay attention to the tools (4) involved and accompany the students in using podcast (5) consider the internet connection (6) find a podcast that appropriate for the students (7) and implement podcast into the related syllabus.

\section{CONCLUSION}

Based on the result of the study, the students and lecturers believed that using British Broadcasting Corporation (BBC) podcast is very useful and necessary. Furthermore, the use of British Broadcasting Corporation (BBC) podcast can give positive contribution to students' listening skill, vocabularies and they will be familiar with listening to British accent. The students' problems when listening to British Broadcasting Corporation (BBC) podcast were unfamiliar pronunciation, lack of vocabularies, and the speakers that speak fast. For the lecturers, the problems were the students' difficulties in listening what the speaker says, the students' limited vocabulary, the podcast consume a lot of time, it is not easy to search for appropriate podcast according to the syllabus, sometimes the information is incomplete, and sometimes the tool doesn't work properly.

\section{ACKNOWLEDGMENTS}

The writer like to express her sincere gratitude to Allah SWT for the blessing bestowed in my life, particularly during the research without which this research would not have done. Thanks to my parents, little sister, big brother, and friends for their valuable endless love, prayer, and support. The writer would like to express her gratitude to my article supervisors, who have 
always supported her while conducting this study. Also, the writer would like to express gratitude to the eight informants of this study, particularly Mam Novanie Sulastri and Mam Hesty Widiastuty, English lecturers at IAIN Palangka Raya. They are willing to serve as a resource person and informant for this study.

\section{REFERENCES}

Agustiana, V. (2019). Listening Anxiety Among Indonesian Efl Students. Indonesian EFL Journal, 5(1), 13. https://doi.org/10.25134/ieflj.v5i1.1607

Al Qasim, N., \& Al Fadda, H. (2013). From CALL to MALL: The effectiveness of podcast on EFL higher education students' listening comprehension. English Language Teaching, 6(9), 30-41. https://doi.org/10.5539/elt.v6n9p30

Arikunto, S. (2010). Prosedur Penelitian Suatu Pendekatan Praktik. Jakarta: PT. Rineka Cipta

Bolla, M. R. (2014). Use of media as an instructional tool in English Language Teaching (ELT) at undergraduate level. International Journal of English and Literature, 5(6), 141-143. https://doi.org/10.5897/ijel2014.0580

Gestanti, R. A. (2017). Journal on English as a Foreign Language Listening Strategies Employed by Non-English. 7(1), 35-58.

Hasan, M. M., \& Hoon, T. B. (2013). Podcast applications in language learning: A review of recent studies. English Language Teaching, 6(2), 128-135. https://doi.org/10.5539/elt.v6n2p128

Indahsari, D. (2020). Using podcast for EFL students in language learning. JEES (Journal of English Educators Society), 5(2), 103-108. https://doi.org/10.21070/jees.v5i2.767

L. Cohen, L. M. \& K. M. (2005). Research Methods in Education 8th Edition.

Lio, A., \& Marafat, L. O. S. (2019). The use of audio podcast for teaching listening comprehension. Journal of Language Education and Educational Technology, 4(1). http://ojs.uho.ac.id/index.php/JLEET/article/view/6671/4901

Maftoon, P., \& Fakhri Alamdari, E. (2020). Exploring the Effect of Metacognitive Strategy Instruction on Metacognitive Awareness and Listening Performance Through a ProcessBased Approach. International Journal of Listening, 34(1), 1-20. https://doi.org/10.1080/10904018.2016.1250632

NamazianDost, I., Bohloulzadeh, G., \& Rahmatollahi, R. (2017). The Effects of Using Podcast on Listening Comprehension among Iranian Pre-intermediate EFL Learners. International Journal of Applied Linguistics and English Literature, 6(6), 57. https://doi.org/10.7575/aiac.ijalel.v.6n.6p.57

Nor, H. (2015). the Techniques in Teaching Listening Skill. Journal on English as a Foreign Language, 4(1), 41. https://doi.org/10.23971/jefl.v4i1.74

Palenque, S. M. (2016). The power of podcasting: perspectives on pedagogy. Journal of Instructional Research, 5(4), 4-7. https://eric.ed.gov/?id=EJ1127626

Prayatni, I. (2019). Teaching english for young learners. In Jurnal Ilmiah Profesi Pendidikan (Vol. 4, Issue 2).

Riau, D.-. (2020). Utilizing Podcast to Improve Informatics Management Students' Listening Comprehension And Participation At Amik Mitra Gama Eka Melati 1, Yessi Ratna Sari 2 , Syamsiah Depalina Siregar 3. 1(2), 64-71.

Si, P. (2019). A Study of the Differences between EFL and ESL for English Classroom Teaching in China. IRA International Journal of Education and Multidisciplinary Studies, 15(1), 32. https://doi.org/10.21013/jems.v15.n1.p4

Silmi, M. R. (2018). Types of Media and Teaching Techniques in Teaching Speaking At Smp Brawijaya Smart School Malang. Suar Betang, 12(2), 223. https://doi.org/10.26499/surbet.v12i2.33 
Sulastri, N. (2011). The effectiveness of picture chart media on students' English vocabulary. Journal on English as a Foreign Language, 1(2), 103. https://doi.org/10.23971/jefl.v1i2.195

Ting, K. Y. (2014). Blended learning as a theoretical framework for the application of podcasting. English Language Teaching, 7(5), 128-135. https://doi.org/10.5539/elt.v7n5p128

Wei, K., \& Ram, J. (2016). Perceived usefulness of podcasting in organizational learning: The role of information characteristics. Computers in Human Behavior, 64, 859-870. https://doi.org/10.1016/j.chb.2016.08.003

Widodo, M. R., \& Gunawan, A. (2019). Investigating The Effect of Using Podcast. LINGUA Jurnal Pendidikan Bahasa Fakultas Keguruan Dan Ilmu Pendidikan | Universitas Islam As-Syafi'iyah, 15(12), 35-42. https://uia.e-journal.id/Lingua/article/view/358

Yusnida, Muslem, \& Manan. (2017). A Study of Teaching Listening. Teaching Learning English, 439-456. http://jurnal.unsyiah.ac.id/EEJ/article/view/9204 